\title{
DESAIN SISTEM MANAJEMEN PENGETAHUAN TUGAS AKHIR STUDI KASUS: PROGRAM STUDI ABC - MALANG
}

\author{
Diah Priharsari, Aditya Rachmadi, Yusi Tyroni, Farhan Nurfadeli \\ Jurusan Sistem Informasi, Program Teknologi Informasi dan Ilmu Komputer, \\ Universitas Brawijaya \\ Jl. Veteran 8, Malang, 65113 \\ Telp: (0341) 577911, Fax: (0341) 577900 \\ E-mail: diah.priharsari@ub.ac.id
}

\begin{abstract}
Final project done by student to prove his ability to research can be classified as knowledge creation activity. Furthermore, creation activity can be managed by a method that is well known as Knowledge Management. Computer application that is used to manage the knowledge is usually called Knowledge Management System. Based on that, this research scrutinized knowledge involved in producing final project as well as tried to develop requirements needed to produce a suitable KMS for ABC. Particularly, this research observed how actors used technology information and all related knowledge creation process especially in developing final project. Only then, problems could be defined from knowledge creation perspective and KMS requirements were yielded. The results of this study were Expert Framework was the most suitable framework for $A B C$ and two requirements that never been realized by $A B C$ was identified: rising star student identification and expert locator identification.

\section{Abstrak}

Pembuatan Tugas Akhir dapat dilihat sebagai proses penciptaan pengetahuan yang dapat dikelola sehingga membantu mempermudah penyelesaian Tugas Akhir. Pengelolaan pengetahuan sering dikenal dengan sebutan Knowledge Management, dengan aplikasi yang terkait disebut Knowledge Management System. Berdasarkan hal tersebut, maka penelitian ini dilakukan untuk pembuatan requirement KMS yang berlandaskan kondisi pengelolaan pengetahuan di ABC. Berdasarkan fokus penelitian tersebut, maka secara khusus yang dihasilkan pada penelitian ini adalah: daftar kebutuhan aplikasi KMS yang dapat membantu pengelolaan pengetahuan di ABC. Dalam rangka menghasilkan kebutuhan tersebut, dilakukan penggalian pada proses pengerjaan TA yang berlangsung di ABC dan aplikasi TI yang mendukung proses pengerjaan TA. Penelitian ini dilanjutkan dengan menghasilkan deskripsi permasalahan pengelolaan pengetahuan di ABC serta kebutuhan sistem KMS yang diharapkan akan membantu pengelolaan pengetahuan di ABC terkait dengan pengerjaan TA. Framework yang sesuai untuk ABC adalah expert framework. Kebutuhan KMS yang diusulkan dan belum pernah dilakukan di $A B C$ sebelumnya adalah identifikasi mahasiswa "rising star" dan "expert locator".
\end{abstract}

Kata kunci: sistem manajemen pengetahuan, tugas akhir, universitas.

\section{PENDAHULUAN}

Knowledge Management adalah memberikan informasi tepat, pada saat yang tepat, dan membantu seseorang menghasilkan pengetahuan serta bertindak terhadap suatu informasi (Brizga \& Geraghty 2011). Knowledge Management System (KMS) adalah metode pendekatan secara sistematis untuk mengelola pengetahuan dengan menggunakan alat dan teknologi (Gil \& Bautista 2012). Peng, Jiang \& Zhang (2013) mengatakan bahwa tujuan utama KMS adalah mendukung penciptaan, penyimpanan, akuisisi, dan transfer pengetahuan di dalam sebuah organisasi. Melihat bahwa proses mendapatkan ide dapat dianggap sebagai proses penciptaan pengetahuan, KMS dapat menjadi sebuah sebuah pendekatan dari teknologi untuk memberikan tambahan dukungan kepada mahasiswa dalam rangka pengerjaan TA (Tugas Akhir/Skripsi). Dengan mengelola pengetahuan dosen serta maha-siswa terkait dengan TA, diharapkan pengulangan penjelasan tidak lagi dilakukan berulang. Selain itu, pengelolaan pengetahuan juga bermanfaat pada dokumentasi ide dan pengetahuan yang berlangsung saat proses pencarian topik maupun bimbingan. Dokumentasi tersebut dapat diakses oleh mahasiswa lain, sehingga proses penciptaan ide baru di kalangan mahasiswa menjadi lebih cepat, mengurangi derajat ketergantungan pada tahap bertemu langsung dengan dosen. 
Hal ini sejalan dengan penelitian Yeh \& Chen (2012) yang menunjukkan bahwa proses dalam KM yang terdiri dari knowledge sharing, knowledge internalization, dan knowledge creation efektif untuk meningkatkan kreativitas mahasiswa, termasuk di dalamnya online sharing yang memberikan efek penting pada peningkatan kreativitas. Terkait dengan hal diatas, permasalahan yang diteliti pada penelitian ini adalah pembuatan requirement KMS yang berlandaskan kondisi pengelolaan pengetahuan di ABC. Berdasarkan fokus penelitian tersebut, maka secara khusus yang dihasilkan pada penelitian ini adalah: daftar kebutuhan aplikasi KMS yang dapat membantu pengelolaan pengetahuan di ABC. Untuk dapat menghasilkan kebutuhan tersebut, dilakukan penggalian pada proses pengerjaan TA yang sesungguhnya berlangsung di $\mathrm{ABC}$ dan aplikasi TI yang mendukung proses pengerjaan TA. Penelitian ini dilanjutkan dengan menghasilkan deskripsi permasalahan pengelolaan pengetahuan di ABC serta kebutuhan sistem KMS yang diharapkan akan membantu pengelolaan pengetahuan di $\mathrm{ABC}$ terkait dengan pengerjaan TA. Seringkali istilah pengetahuan dibandingkan dengan istilah data serta informasi (Brizga \& Geraghty, 2011; Davenport \& Prusak, 2000; Nonaka \& Konno, 1998). Perbedaan yang mendasar antara informasi dengan pengetahuan adalah adanya pengalaman, keahlian yang menempel pada individu. Knowledge Management adalah memberikan informasi tepat, pada saat yang tepat, dan membantu seseorang menghasilkan pengetahuan serta bertindak terhadap suatu informasi (Brizga \& Geraghty, 2011). Menurut Pusat produktifitas dan kualitas Amerika, KM adalah strategi dan proses melakukan identifikas, menangkap, dan meningkatkan pengetahuan (Allameh, Zare \& Davoodi, 2011). Accenture menggambarkan framework KM (Gambar 1) dalam sebuah matriks yang terdiri dari dua dimensi, yaitu kompleksitas kerja serta tingkat kolaborasi kelompok yang diperlukan. Kerangka kerja yang diusulkan oleh Accenture berdasar pada knowledge sebagai sebuah kapasitas sehingga KM diperlukan untuk meningkatkan keunggulan kompetitif perusahaan untuk berhasil. Pada setiap kelompok model, tantangan untuk mencapai keunggulan kompetitif yang dihadapi oleh sebuah perusahaan akan berbeda. Misalnya, kelompok model integrasi akan menghadapi tantangan mengharmoniskan kerja antar bagian yang berbeda, di kelompok model kolaborasi, mencapai inovasi menjadi tantangan, pada model transaksi yang menjadi tantangan adalah konsistensi dan biaya performansi yang rendah, sedangkan pada model expert mendapatkan hasil dari individu unggul menjadi tantangan.

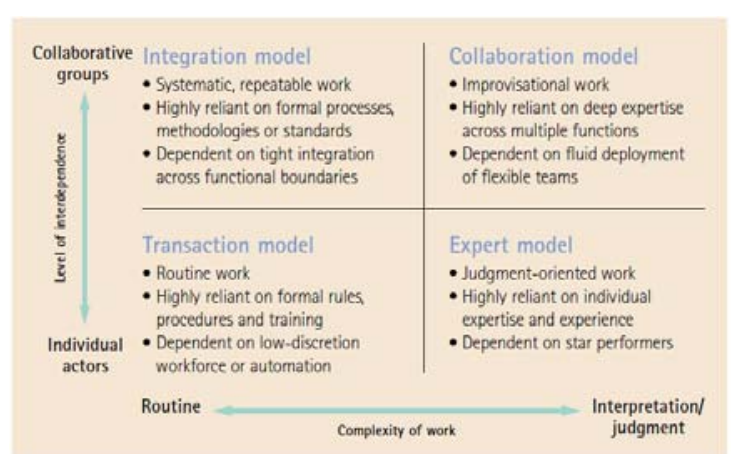

Gambar 1 Framework KM menurut Accenture (Donogue, Harris \& Weitzman, 1999)

\section{METODOLOGI}

Penelitian ini bertujuan untuk menghasilkan kebutuhan KMS. Sesuai dengan definisi bahwa KMS adalah sistem berbasis komputer yang membantu pengelolaan pengetahuan, maka dalam rangka menghasilkan desain KMS, langkah awal yang dilakukan adalah mengetahui terlebih dahulu praktik KM yang sedang berjalan di ABC. Untuk mengetahui praktik KM yang ada di ABC dilakukan wawancara serta penelusuran dokumen akademik yang ada. Praktik KM yang ada dievaluasi dengan menggunakan pengukuran kinerja KM. Karena obyek penelitiannya berupa proses dengan sedikit kontrol dari peneliti, maka studi kasus adalah metode yang tepat untuk dipilih (Chua dan Pan, 2008; Balaji dan Ahuja,2006).

Yin (1994) mengidentifikasi 6 sumber data utama dalam penelitian yaitu: dokumentasi, rekaman, wawancara, pengamatan langsung, pengamatan participant, dan data fisik. Proses KM saat ini sedang berlangsung, sehingga data utama selain didapatkan dengan data fisik dan wawancara, juga dilakukan pengamatan langsung. Yin juga menunjukkan bahwa hubungan logis data dengan proposisi serta kriteria dalam menginterpretasi adalah hal yang penting dalam penelitian. Gambar 2 menunjukkan langkah-langkah yang dilakukan pada penelitian ini serta landasan yang digunakan untuk menentukan kriteria temuan.

Kualitas penelitian ditunjukkan dengan: validitas konstruk, validitas internal, validitas eksternal, dan reliabilitas (Yin, 1994). Validitas konstruk mengukur seberapa baik suatu penelitian meneliti yang harus diteliti. Yin menunjukkan cara untuk menghindari subyektifitas dengan :a) menggunakan sumber lebih dari satu, b) sumber yang relevan, c) draft studi kasus ditinjau ulang oleh sumber kunci. Pada penelitian ini dipilih sumber yang relevan yaitu karyawan, mahasiswa, dan dosen. Selain itu dilakukan juga pengolahan data akademik untuk memvalidasi hasil yang didapat dari wawancara jika bisa. 


\subsection{Studi lapangan}

Bertujuan untuk mengetahui proses yang berlangsung saat ini saat mahasiswa mengajukan judul TA, terutama pada tahap mencari topik. Untuk mendapatkan gambaran mengenai sistem $\mathrm{KM}$ terkait pengerjaan $\mathrm{TA}$ di $\mathrm{ABC}$, wawancara dilakukan pada aktor yang terlibat pada pengembangan proposal TA yaitu dosen dan mahasiswa. Data wawancara dilengkapi dengan penelusuran dokumen di sistem akademik, mempelajari sistem aplikasi yang mendukung proses pencarian topik TA yang ada di $\mathrm{ABC}$, serta proses bisnis yang mendukung proses pencarian topik TA. Pengamatan dilakukan oleh peneliti sebagai pelaku dari sistem. Strategi yang dilakukan untuk studi lapangan adalah sebagai berikut.

\section{a. Survei dokumen}

Dokumen pengerjaan TA didapatkan dari akademik. Didapatkan total data 205 mahasiswa yang telah lulus di tahun 2014 dan tahun 2013 serta 761 data keseluruhan mahasiswa yang telah mengambil TA. Data tersebut berisi: nama mahasiswa, tanggal pengajuan KRS, tanggal sidang, tanggal pengajuan judul TA, tanggal keluar nama pembimbing, laboratorium, dan nama dosen pembimbing. Data tersebut adalah seluruh data mahasiswa yang lulus di bawah program $\mathrm{ABC}$ ( $\mathrm{ABC}$ baru resmi berdiri pada tahun 2011) yang terdiri dari pengambilan SKS, pembimbing, tanggal seminar progress, tanggal sidang. Data sebelumnya tidak berhasil didapatkan karena masih berada di bawah Fakultas Teknik dan Fakultas MIPA. Survei dokumen dilakukan untuk melihat pola-pola yang mungkin dapat menunjukkan bagaimana proses pengerjaan TA di ABC berlangsung.

\section{b. Wawancara dosen kepala laboratorium}

Total terdapat 6 laboratorium yang menaungi pengerjaan TA, yaitu: Sistem Informasi, Rekayasa Perangkat Lunak, Game, Kecerdasan Buatan, Jaringan, dan Robotika. Dosen kepala laboratorium dipilih untuk mewakili unit laboratorium. Pada pembahasan, nama laboratorium disamarkan.

Wawancara dengan dosen kepala laboratorium lebih difokuskan pada keterlibatan laboratorium pada proses mahasiswa dalam mencari topik TA dan bimbingan TA. Dosen kepala laboratorium dipilih untuk mewakili laboratorium. Walaupun banyak komponen yang terlibat dalam laboratorium dan kepala laboratorium mungkin tidak dapat mewakili seluruh perspektif yang ada pada laboratorium, akan tetapi kepala laboratorium dianggap sebagai pihak yang paling mengetahui seluruh proses pada laboratorium sekaligus pengambil kebijakan terkait dengan proses pada laboratorium.

\section{c. Kuisioner untuk lulusan ABC}

Disebarkan total 107 kuisioner pada mahasiswa yang telah lulus (dari total populasi sebesar 205). Mahasiswa yang telah lulus dipilih karena dianggap mengetahui proses pengerjaan TA dari awal hingga akhir sehingga dapat memberikan pendapat berdasarkan pengalaman yang lebih utuh. Berdasarkan kecukupan data yang dituliskan Oates (2006), setidaknya dibutuhkan 30 sample untuk melakukan survei sehingga 107 kuisioner yang kembali dapat dianggap telah memenuhi kecukupan data. Kuisioner ini bertujuan untuk mengetahui proses mahasiswa saat mengerjakan TA. Kuisioner dipilih karena kuisioner dianggap lebih praktis daripada wawancara mengingat wawancara membutuhkan waktu yang tidak sedikit sementara mahasiswa yang telah lulus tersebut telah bekerja di berbagai daerah luar Malang.

d. Wawancara pada mahasiswa yang sedang mengambil TA

Dilakukan wawancara pada mahasiswa sebanyak 70 orang yang masih mengerjakan TA untuk mendapatkan pengetahuan mengenai proses TA yang saat ini berlangsung. Wawancara dipilih karena kelebihan wawancara yaitu dimungkinkan untuk proses timbal balik pertanyaan apabila diperlukan.

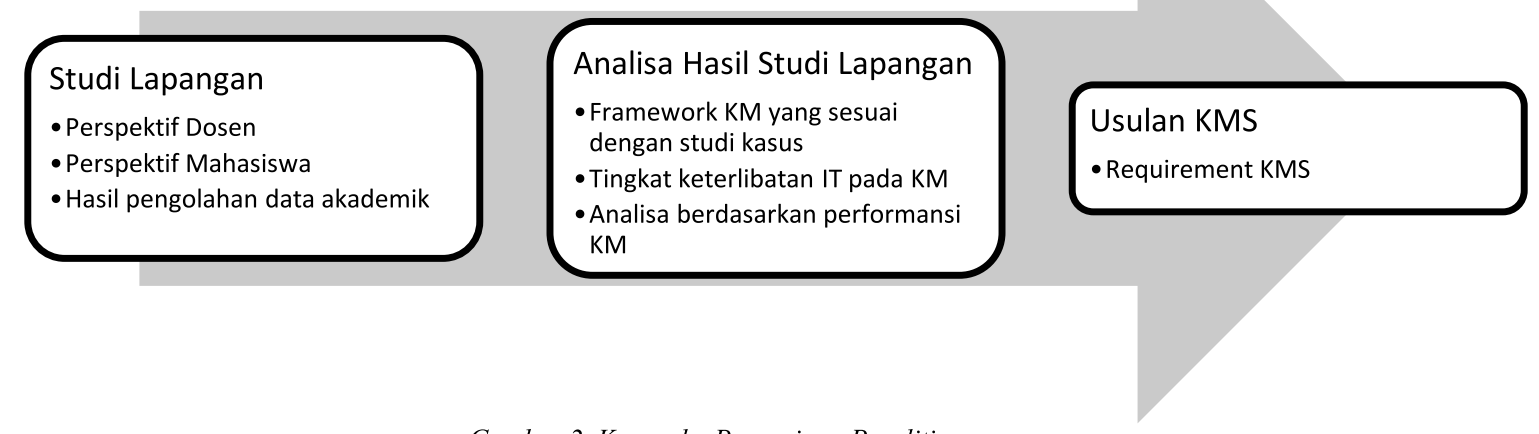

Gambar 2. Kerangka Pengerjaan Penelitian 
e. Kuisioner untuk dosen pembimbing

Disebarkan kuisioner kepada seluruh dosen aktif di ABC (total 44), akan tetapi jumlah kuisioner yang kembali hanya berjumlah 28. Jumlah ini tidak memenuhi kebutuhan minimal yaitu 30 sample, akan tetapi pada penelitian ini masih dapat dianggap mewakili karena berdasarkan persentasi, maka total kuisioner yang kembali adalah $64 \%$ dari total populasi. Kuisioner disebarkan ke dosen untuk mengetahui keterlibatan dosen pada Monita dan aktifitas yang dilakukan dosen untuk membantu memperkenalkan topik skripsi dan persepsi dosen mengenai kelayakan skripsi mahasiswa yang telah lulus. Kuisioner dipilih karena lebih praktis daripada wawancara.

\subsection{Analisa Hasil Studi Lapangan}

Hasil studi lapangan akan dipetakan pada proses penciptaan pengetahuan. Selain itu berdasarkan hasil lapangan akan diidentifikasi tingkat keterlibatan IT pada KM sekaligus mengidentifikasi framework yang sesuai. Selain itu dihasilkan deskripsi infrastruktur yang ada serta analisa berdasarkan KMPI yang diajukan oleh Lee, Lee \& Kang (2005) pada proses pengelolaan pengetahuan yang ada saat ini.

\section{HASIL dan PEMBAHASAN}

Di ABC, keterlibatan dosen pada proses pengerjaan TA dimulai dari mahasiswa memasukkan atau mencari judul/tema TA. Karakter TA di ABC berbeda dibandingkan perkuliahan umum di kelas. Berikut ciri pembeda pengerjaan TA:

1. Setiap mahasiswa memiliki proyek penelitian yang berbeda dengan kompleksitas yang berbeda-beda.

2. Setiap mahasiswa dibimbing oleh dua dosen dengan keahlian yang berbeda.

3. Keterlibatan dosen dimulai setelah mahasiswa menghubungi dosen atau mengajukan topik TA.

Karakter pembeda tersebut menyebabkan desain KMS yang telah dibuat oleh Peng maupun yang diteliti oleh Yeh tidak dapat digunakan begitu saja. Dibutuhkan modifikasi yang sesuai dengan karakter khusus pengerjaan Tugas Akhir. Pada penelitian ini, sebelum dilakukan desain KMS, maka dilakukan terlebih dahulu analisa framework yang sesuai dengan karakter pengerjaan TA.

Berdasarkan tingkat ketergantungan, sesuai dengan aturan akademik, pengerjaan TA dilakukan oleh perseorangan, sedangkan ditinjau dari kompleksitas pekerjaan, pengerjaan TA bergantung pada penilaian. Hal ini dapat dibuktikan dari adanya meeting lab yang dilakukan salah satu lab yang menunjukkan bahwa kelayakan topik TA sangat bergantung pada penilaian sekitarnya. Berdasarkan hal tersebut dapat disimpulkan bahwa framework KM yang sesuai dengan khusus untuk pengerjaan TA adalah expert model.

Berdasarkan framework KM yang dibuat oleh Donogue, Harris \& Weitzman (1999), Expert Model lebih ditekankan pada kinerja individual dan merupakan kegiatan dengan keunikan masing-masing yang berbeda kompleksitasnya. Tantangan yang dihadapi oleh model ini adalah menemukan individu unggul. Walaupun konteks framework tersebut diperlukan untuk organisasi yang ingin meningkatkan kapabilitasnya dalam mencapai keunggulan kompetitif, namun dengan adanya kesamaan tipe kompleksitas dan tingkat kolaborasi, maka framework tersebut.

Walaupun telah ditunjukkan bahwa ABC sudah memiliki beberapa aplikasi yang membantu pengelolaan pengetahuan khususnya pengerjaan TA, namun belum ada satupun aplikasi yang dibuat membantu mencari individu unggul. Sementara ini, pengetahuan mahasiswa yang unggul dalam proses penelitian individu maupun dosen yang dapat membimbing mahasiswa hingga mampu mencapai tahap pemahaman lebih masih tersimpan di transkrip SIAKAD dan benak mahasiswa rekannya serta dosen itu sendiri. Dengan kata lain, dukungan TI yang ada untuk $\mathrm{KM}$ expert model di $\mathrm{ABC}$ masih berada pada level 1 yaitu dosen-mahasiswa ke aplikasi.

Monita sebagai sebuah sistem informasi yang membantu menyebarkan data tugas akhir memang dapat dimanfaatkan untuk mengetahui topik TA yang ditawarkan dosen serta melihat daftar pengajuan judul skripsi oleh mahasiswa. Namun terkait dengan framework expert model tidak terdapat fungsi-fungsi yang dibutuhkan untuk mengetahui informasi individu unggul seperti TA seperti apa yang dikerjakan oleh mahasiswa tersebut, siapa pembimbingnya, bagaimana usulan pengembangan TA tersebut. Secara umum dapat dikatakan bahwa sudah terdapat inisiasi pengelolaan pengetahuan terkait TA, yaitu dengan adanya Monita. Walaupun begitu, keberadaan Monita saat ini terlihat belum mendukung kerangka kerja pengelolaan KM expert model. Tabel 1 adalah rangkuman kebutuhan KMS yang dibutuhkan oleh ABC.

\section{SIMPULAN dan SARAN}

Penelitian ini memberikan kontribusi yaitu menunjukkan tahapan yang dilakukan ketika suatu organisasi ingin memulai mengelola pengetahuan yang dimilikinya. 
Tabel 1. Rangkuman Kebutuhan KMS ABC

\begin{tabular}{|c|c|c|}
\hline PENGETAHUAN & SUMBER DATA & USULAN KMS \\
\hline $\begin{array}{l}\text { Kemajuan } \\
\text { pekerjaan TA } \\
\text { mahasiswa, } \\
\text { kesulitan saat } \\
\text { pengerjaan TA }\end{array}$ & $\begin{array}{l}\text { Lembar bimbingan. } \\
\text { Literatur dan } \\
\text { dokumentasi yang } \\
\text { dikumpulkan selama } \\
\text { pengerjaan. }\end{array}$ & $\begin{array}{l}\text { Knowledge creation : data disimpan pada basis data. Harus } \\
\text { terdapat bagian yang memungkinkan dituliskan kemajuan } \\
\text { mahasiswa dengan detail. } \\
\text { Knowledge sharing : data dapat diakses oleh dosen maupun } \\
\text { mahasiswa kapan saja } \\
\text { Knowledge reuse : data dapat digunakan oleh mahasiswa lain atas } \\
\text { persetujuan mahasiswa yang memiliki lembar bimbingan tersebut. }\end{array}$ \\
\hline $\begin{array}{l}\text { Perkembangan } \\
\text { keilmuan yang } \\
\text { didapat dari hasil } \\
\text { TA }\end{array}$ & $\begin{array}{l}\text { Catatan dosen. } \\
\text { Literatur yang } \\
\text { dikumpulkan. }\end{array}$ & $\begin{array}{l}\text { Knowledge creation : data disimpan pada basis data } \\
\text { Knowledge sharing : data dapat diakses oleh dosen maupun } \\
\text { mahasiswa kapan saja } \\
\text { Knowledge reuse : data dapat digunakan oleh mahasiswa lain } \\
\text { dengan adanya pengklasifikasian keilmuan berdasarkan dosen dan } \\
\text { mahasiswa yang memasukkan literatur maupun yang telah } \\
\text { membaca dokumen tersebut. }\end{array}$ \\
\hline $\begin{array}{l}\text { Mahasiswa "rising } \\
\text { star" }\end{array}$ & Dosen & $\begin{array}{l}\text { Knowledge creation : dosen dapat memberikan catatan-catatan } \\
\text { mengenai pemahaman mahasiswa } \\
\text { Knowledge sharing : data dapat diakses oleh dosen maupun } \\
\text { mahasiswa kapan saja } \\
\text { Knowledge reuse : data dapat digunakan oleh mahasiswa lain } \\
\text { dengan adanya pengklasifikasian keilmuan }\end{array}$ \\
\hline Expert locator & Dosen, mahasiswa & $\begin{array}{l}\text { Knowledge creation : Mahasiswa maupun dosen dapat } \\
\text { menambahkan kelompok pengetahuan yang sudah didapatkan } \\
\text { mahasiswa atau dosen tersebut. } \\
\text { Knowledge sharing : mahasiswa ataupun dosen dapat } \\
\text { menghubungi dosen atau mahasiswa tersebut ataupun mengetahui } \\
\text { profil terkait dan pengelompokan pengetahuan tersebut. }\end{array}$ \\
\hline
\end{tabular}

Tidak hanya kerangka pengelolaan pengetahuan tetapi juga menunjukkan keterkaitan antara pengelolaan pengetahuan dan KMS yang mendukung kerangka KM. Literatur yang sering dijumpai adalah perancangan KM, namun sulit didapatkan literatur yang menunjukkan secara menyeluruh dari kerangka kerja KM sampai menghasilkan requirement KMS yang mendukung kerangka kerja tersebut.

Penelitian ini sangat terbatas pada area pengetahuan yang terkait dengan pengerjaan TA dan proses bisnis yang terkait langsung, padahal pengetahuan terkait TA bisa didapatkan tidak hanya pada tahapan langsung saat TA. Pengetahuan yang dapat mempercepat mengerjaan TA mungkin didapatkan dari pengalaman tugas pada mata kuliah yang lalu maupun kegiatan ekstrakurikuler yang ada di kampus. Keterbatasan lainnya adalah metode yang dilakukan untuk melakukan evaluasi kinerja pengelolaan pengetahuan. KMPI yang digunakan ditujukan bagi perusahaan yang melihat pengetahuan yang dimiliki oleh karyawannya dikaitkan dengan nilai perusahaan. Sedangkan pada penelitian ini, pengetahuan yang dikelola dipandang sebagai sebuah proses dengan pihak yang terlibat adalah bukan hubungan pegawai-atasan melainkan researcher dan co-researcher, atau pembimbing dengan muridnya, sehingga seharusnya komponen penilaian pada KMPI diadaptasi agar lebih sesuai.

Walaupun reliabilitas penelitian ini berusaha ditingkatkan dengan menggunakan protokol pada saat wawancara, akan tetapi sekali lagi, interpretasi hasil wawancara sangat dipengaruhi oleh interpretasi pewawancara. Sementara validitas konstruk ditingkatkan dengan menggunakan sumber lebih dari satu (dosen, staff, bahkan data akademik). Sedangkan tingkat generalisasi penelitian ini masih harus diuji sebab studi kasus hanya dilakukan pada satu tempat yaitu di $\mathrm{ABC}$.

\section{DAFTAR RUJUKAN}

Alavi, M., Leidner, D.E., 2001. Review: knowledge management and knowledge management systems: conceptual foundations and research issues, MIS Quarterly Vol 25, pp. 107-136.

Allameh, S.M., Zare, S.M. and Davoodi, S.M.R. 2011. Examining the impact of $\mathrm{KM}$ enablers on knowledge management processes, Procedia Computer Science, Vol. 3. pp 1211-1223(World Conference on Information Technology). 
Priharsari, dkk., Desain Sistem Manajemen Pengetahuan Tugas Akhir, Studi Kasus: Program Studi..

Balaji, S., Ahuja, M. 2006. Offshore Software Projects: Assesing the Effect of Knowledge Transfer Requirement and ISD Capability. Proceedings of 39th Hawaii International Conference on System Science.

Brizga, S., Geraghty, P. 2011. Strategic Framework For Integrated Natural Resource Knowledge Management. Victorian Catchment Management Council.

Chua, A. 2004. Knowledge Management Architecture: A bridge Between KM Consultants And Technologists. International Journal of Information Management. pp 87-98.

Chua, A., Pan, S. 2007. Knowledge Transfer and Organizational Learning in IS Offshore Sourcing. International Journal of Management Science Omega, 36. Pp 267281.

Davenport, T.H., Prusak, L. 2000. Working Knowledge: How Organizationa Manage What They Know. Harvard Business School Press. USA.

Donoghue, L.P., Harris, J.G., Weitzman, B.A., 1999. Knowledge Management Strategies That Create Values.Outlook Vol. 1, pp 4853.

Gil, R.J., Bautista, M., 2012. A novel integrated knowledge support system based on ontology learning: Model specification and a case study. Knowledge-Based Systems vol 25. pp 340-352

Gottschalk, P. 2006. Stages of knowledge management systems in police investigations. Knowledge-Based Systemvol 19. pp 381-387.

Lee, K.C., Lee, S., Kang, I.W., 2005. KMPI: Measuring Knowledge Management Performance. Information \& Management Vol. 42. pp 469-482
Mohayidin,M.G., Kamaruddin, M.N., Margono, M.I. 2007. The Application of KM in Enhancing The Performance of Malaysian Universities. The Electronic Journal of KM Vol 5 Issue 3.pp 301-312. Dapat diakses di www.ejkm.com

Nonaka, I., Takeuchi, H. 1995. The knowledgecreating company. New York: Oxford University Press.

Nonaka, I., Konno, N. 1998. The Concept of Ba: Building a foundation for knowledge creation. California Management Review Vol 40, No. 3. pp 40-54.

Oates, B.J. 2006. Resarching Information Systems \& Computing. Sage Publications Ltd.

Peng, J., Jiang, D., Zhang, X. 2013. Design and Implement a Knowledge Management System to Support Web-Based Learning in Higher Education. Procedia Computer Science.pp 95-103

Stewart, T.A. 2002. The Case Against Knowledge Management. Diakses Juni 10, 2012, dari situshttp://www.iwp.jku.at/born/mpwfst/06/ cogneon/The_Case_Against_KM.pdf

Tow, W., Venable, J., Dell, P. 2012. How Organization Know What They Know: A Survey of Knowledge Identification Methods Among Australian Organization.23rd Australasian Conference on Information System.

Yeh, Y., Chen, Y. 2012. From Knowledge Sharing to Knowledge Creation:A Blended Knowledge Management Model for Improving University Student's Creativity.Thinking Skills and Creativity. pp 245-247.

Yin, R. 1994. Case study Research: Design and Methods, Second Edition. California: Sage Publications, Inc. 